\title{
Kernos
}

Revue internationale et pluridisciplinaire de religion grecque antique

30 | 2017

Varia

\section{The Life of Statues of Gods in the Greek World}

\section{Angelos Chaniotis}

OpenEdition

Journals

Electronic version

URL: http://journals.openedition.org/kernos/2492

DOI: $10.4000 /$ kernos. 2492

ISSN: 2034-7871

\section{Publisher}

Centre international d'étude de la religion grecque antique

\section{Printed version}

Date of publication: 1 October 2017

Number of pages: 91-112

ISSN: 0776-3824

Electronic reference

Angelos Chaniotis, «The Life of Statues of Gods in the Greek World», Kernos [Online], 30 | 2017, Online since 01 October 2019, connection on 17 September 2020. URL : http://journals.openedition.org/ kernos/2492 ; DOI : https://doi.org/10.4000/kernos.2492

This text was automatically generated on 17 September 2020.

Kernos 


\title{
The Life of Statues of Gods in the Greek World
}

\author{
Angelos Chaniotis
}

This a revised version of a lecture at the University of Liège on March 18, 2016. I am very grateful to Vinciane Pirenne-Delforge for her suggestions and to Dr. Henry Heitmann-Gordon (Munich) for correcting the English text.

\section{Lives of statues}

1 On February 10, 2012, the international press reported an incident that occurred in the Siberian town of Uzhur.

An unemployed Russian man has climbed on to a statue of Lenin and set himself on fire, suffering serious burns. "After climbing the steps up to the pedestal of the Lenin monument, the man set fire to himself and, engulfed in flame, fell to the ground," the police for the Krasnoyarsk region of Siberia said in a statement. The man, 51, climbed on the statue in front of a district administration building in the town of Uzhur, but made no demands before pouring petrol on himself and lighting a match. ${ }^{1}$

2 Statues of Lenin in the former Soviet Union - more than sixty still exist in Moscow alone - and statues of Kemal Atatürk in modern Turkey share certain features with ancient Greek divine images: they are omnipresent - as diffused as statues of saints in Catholic churches; they follow certain iconographic conventions; they arouse strong emotions; they are the object of worship. On 30 August 2000, in a parade for Victory Day in Izmir, I saw a man, draped in a Turkish flag, running to the statue of Kemal Ataturk and embracing it. And precisely because such emblematic statues of statefounders are objects of worship, express values, and arouse emotions, they also have a lifespan. When the worship ends and the emotions that they arouse are not the positive emotions of affection, loyalty, faith, gratitude, or pride, but hatred, indignation, or contempt, then statues reach the end of their lives, unless their function changes and they are collected or displayed as curiosities or works of art. 
We may observe similar changes of fortune in the lives of Greek divine statues. But in many respects these changes are more complex, not the least because of the fundamental significance of statues for Greek religion. Although divine statues or other divine images were not an indispensable element in the worship of the gods, ${ }^{2}$ they did enhance worship, in particular through their emotive power. It is not a coincidence that the Christians used a term that highlights the importance of statues to label polytheistic worship, calling it idolatry.

4 We usually associate statues with immobile and immutable matter. We use expressions such as 'he stood like a statue'. Such an expression is connected with the idea that statues are incapable not only of movement but also of feeling and cognition. 'She stood like a statue' is the title of a poem of Chris Vailancourt, ${ }^{3}$ which ends with the verses: 'She stood like a statue. | Beautiful as marble.| But utterly, totally, | completely empty inside.' Similar ideas existed in ancient Greece. The usual attributes of statues are

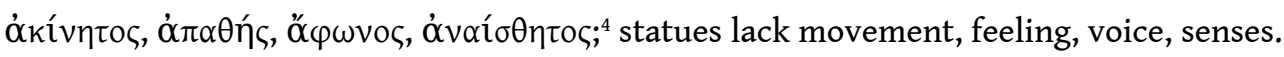

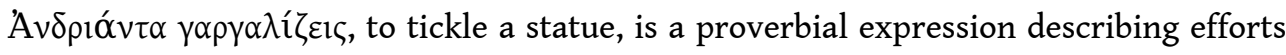
made in vain. ${ }^{5}$

5 If statues were perceived as lifeless matter, can we then speak of 'the life of statues'? This would be a very short study, if I were to give a negative answer. My answer is affirmative. Statues of gods in Greek culture had lives, not only metaphorically but also literally - and up to a certain extent this applies to statues of mortals as well.

6 First, statues have lives in the Greek sense of bios: they have biographies. Statues came into being; they served functions and were the focal point of rituals; they were observed and talked of; they had adventures and travelled; they were destroyed and buried. It is in this sense that the expression 'life of statues' has been used by art historians and historians. ${ }^{6}$ Second, statues have a life also in the sense that they have agency: by arousing emotions, they provoke actions that are beyond or contrary to human intentions. ${ }^{7}$ And thirdly, statues of gods are perceived, under certain conditions, as fulfilling vital functions: they become alive. They move, speak, sweat, tremble, and heal. ${ }^{8}$ In the latter cases divine images were receptacles and media of a god's epiphany. ${ }^{9}$ These three different ways in which divine statues have lives are interlinked but should nevertheless be kept apart.

\section{The ritual lives of statues of gods}

7 Let me start with the first, metaphorical use of the expression 'life of statues', a subject that has attracted a lot of attention in the past. Statues of gods had lives after they left the sculptor's workshop and before they fell off their bases, pushed by men or shaken by earthquakes. This life began with the dedication of a statue. The accompanying rituals are hardly ever mentioned in the literary sources. What little we know about the consecration of statues of gods has been collected and discussed by Vinciane PirenneDelforge. ${ }^{10}$ It is thanks to inscriptions that we know that the erection of a statue, either of a god or of a mortal, was celebrated as a festival of great publicity at the latest from the Hellenistic period on - despite the undeniable influence of foreign religions on Hellenistic practices, I suspect that these celebrations have their origins in earlier periods. A decree of Magnesia on the Maeander concerns the placement of the old cult image of Artemis Leukophryene in her newly constructed Parthenon in the early second century BCE. The rituals included a procession, a sacrifice, and the singing of 
hymns. All the women were to come to the temple and attend on the goddess, i.e. probably decorate her statue. ${ }^{11}$ This event, which took place on the goddess' birthday (6th of Artemision), was then annually commemorated in the festival Isiteria.

8 The ceremonial dedication of the statue of a divinity certainly served as the model for

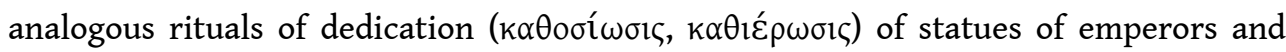
benefactors. For this reason, information concerning the consecration and erection of statues of mortals ${ }^{12}$ gives us, up to a certain extent, some idea about the festivities that accompanied the consecration of divine images in the Hellenistic and Imperial periods. E.g. in Iasos, the high priest of Septimius Severus and his sons organized a sacrifice when the statues of the emperors were dedicated, providing wreaths for those who attended it, distributing old aromatic wine during the banquet that followed, providing the athletes with olive oil, and organizing a market-fair. ${ }^{13}$ We find here all the typical elements of a festival: sacrifice, banquet, market, and contests. The contemporary consecration of cult images in temples was probably celebrated as festivals in the same manner. In the Hellenistic and Imperial periods there were also rituals for the erection

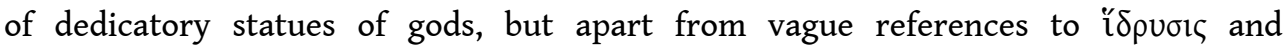

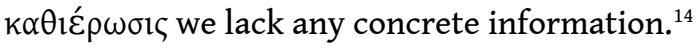

After their ceremonial erection divine statues remained a focal point of interest and continual treatment. They were regularly cleaned, washed, dressed, and perfumed. ${ }^{15}$ The accounts of the hieropoioi at Delos list the regular expenses for the decoration and cleaning of statues. ${ }^{16}$ Statues played an important part in ritual dramas, e.g., in rituals of sacred marriage ${ }^{17}$ in rituals that celebrated the periodic arrival of gods, ${ }^{18}$ and in the ritual banquet for gods, the theoxenia. ${ }^{19}$ In Magnesia on the Maeander the stephanephoros carried images of the Twelve Gods, dressed in the most beautiful garments. ${ }^{20}$ These images were brought to the Agora, where a tent with a triklinon was prepared next to the altar of the Twelve Gods. Displaying their statues in this way represented the presence of the supernatural guests.

The carrying of statues in processions is already attested in early periods (see note 18, on the periodic arrival of gods) but it gained popularity in the Hellenistic period. Images of gods were prominent in the great procession staged by Ptolemy II in Alexandria (ca. $274 \mathrm{BCE}$ ) and in the Ephesian celebration initiated by Vibius Salutaris. ${ }^{21}$ Expressions such as $\theta \varepsilon \circ \varphi$ ópoৎ (the individual who carries images of gods) ${ }^{22}$ and $\alpha$ $\gamma \alpha \lambda \mu \alpha$ $\pi \circ \mu \pi \kappa o ́ v$ (processional statue) ${ }^{23}$ are directly connected with this practice.

11 A second-century-CE decree from Stratonikeia illustrates the significance of statues as the focal point of rituals in the Imperial period. Thirty young boys, dressed in white, with wreaths and branches in their hands, were to come in a procession to the bouleuterion; there, they were to stand in front of the statues of Zeus and Hekate and sing a hymn, every morning. ${ }^{24}$ The visit to the statues welcomed the new day.

\section{Itinerant divine statues}

Travel is a very common aspect in the life of divine statues. The literary tradition knows of divine images that fell from the sky or were carried by heroes and brought to places where a new cult was founded, and both literary sources and inscriptions refer to the involuntary journeys of statues, victims of war and theft. I mention only a few inscriptions concerning the latter phenomenon, the violent removal of divine images. 
In a letter sent by Octavian to Ephesos, the adoptive son of Caesar requested the return of a statue of Eros, originally dedicated by Caesar to Aphrodite in Aphrodisias, then carried away as booty by Labienus and dedicated to the Ephesian Artemis (38 BCE). ${ }^{25}$ Not without a sense of humor, Octavian added that a statue of Eros was not a suitable dedication for the virgin goddess of the Ephesians. Another statue of Eros, far more famous, a work of Praxiteles, led a yet more adventurous life. It was removed from Thespiai by Mummius in $146 \mathrm{BCE}$ and given to Athens where it was displayed in the theater of Dionysos, together with Praxiteles' statue of Nike; it was returned to Thespiai, probably after Sulla's victory in $87 \mathrm{BCE}$, because of Thespiai's support and Sulla's particular connection with Venus/Aphrodite. The festival of Eros was probably re-organized under the new name Erotidaia Rhomaia after the return of the statue. It was later taken to Rome, returned to Thespiai under Claudius, taken again by Nero and finally destroyed by fire in Rome around $80 \mathrm{CE} .{ }^{26}$

13 A decree of Pydna concerning the restoration of the statue of Apollo Dekadryos may allude to a similar story of removal and return. The priest and two citizens of Pydna were sent as envoys to Karponidas and Alexiphaes of Demetrias. Accepting Pydnas' request, the two men restored the statue. ${ }^{27}$ It has been assumed that they were sculptors, honored for repairing a statue damaged by the Romans in $168 \mathrm{BCE}$ or for replacing a statue lost during the temple's pillaging. But the two men are neither designated as sculptors nor are they known as sculptors from other sources. It is more likely that they were in possession of the statue (as traders of war booty) and agreed to return it to Pydna.

Another interesting case of a traveling divine image is that of the bronze statue of Herakles from Seleukeia on the Tigris. ${ }^{28} \mathrm{~A}$ bilingual Greek-Aramaic inscription (ca. $151 \mathrm{CE}$ ) records a campaign of the Parthian king Vologeses IV against king Mithradates of Messene. After his victory, Vologeses brought the statue to Seleukeia and dedicated it in the temple of Apollo 'who presides over the brazen gate'. The Aramaic text identifies Herakles with Vahram and Apollo with Nebo. The transportation of statues, especially statues of kings and patron gods, from defeated cities to the capital of the victor was often practiced in the ancient Near East. ${ }^{29}$ Herakles, whose image figured on the coins of Messene, must have been the patron of this kingdom; the abduction of his statue from Messene and its dedication in the sanctuary of another deity (Apollo) in Seleukeia symbolized not only the complete submission of this kingdom to Vologeses IV, but also the transfer of his protective powers to Vologeses' capital. The statue of Herakles was placed in a temple near the 'bronze gate' because of the apotropaic powers attributed to Herakles (protector of gates) and Apollo Propylaios.

But divine statues did not have to wait for a war to travel the world; sometimes they were stolen from temples. This was the fate of the cult statue of Hephaistos in Argos (first century CE),$^{30}$ and of yet another statue of Eros from Laodikeia $(254 \mathrm{CE}) \cdot{ }^{31}$ Violence was part of the life - or ended the life - of statues.

\section{Peripeties of divine statues: destruction and repair}

16 Although the destruction of statues is closely associated with the rise of Christianity and the attacks on eidola ${ }^{32}$ statues of gods have a history of being maltreated, vandalized or attacked already much earlier. If we are to believe Lucian, the statue of 
Hermes Agoraios in Athens was covered with bitumen, as sculptors made casts to produce copies. ${ }^{33}$ The additional, movable parts of statues, often made of precious metal, could be removed, and the story goes that a man in Kroton was convicted to death for taking the golden beard that had fallen off the statue of Pythagoras. ${ }^{34}$ An inscription from Kollyda reports that during the celebration of a festival in $197 \mathrm{CE}$ people came together and marched against a sanctuary. Armed with swords, sticks and stones, they attacked the sacred slaves and smashed the statues of the gods..$^{35}$

Another potential part of the life of statues was their repair and re-dedication, especially when they had a particular value for a community or family. The rededication of honorific statues and statue-bases of mortals is a phenomenon that has attracted significant attention in recent research, especially with regard to statues and statue-bases of the Archaic and Classical period re-used to honor Romans in Athens. ${ }^{36}$ R.R.R. Smith and C.H. Hallett have recently reconstructed the fascinating story of a statue group of Achilles and Troilos in Aphrodisias, from its original dedication in the first century $C E$ and its later repair to its erection in the civic basilica in the midfourth-century CE. ${ }^{37}$ As late as the third or fourth century CE, the Milesians restored a statue of Neileus, the legendary founder of their city, in the South Market. ${ }^{38}$

The restoration of the statues of gods is less often directly attested. This is not surprising, since cult statues were regularly taken care of, cleaned, decorated, and repaired. We have more information about private initiatives for the repair and rededication of divine images, especially when they were somehow connected with an individual or his family. A few characteristic examples may serve to illustrate this. Sometime during Caesar's (or Octavians's) rule in Rome an anonymous man at Aphrodisias dedicated a statue of Nike and probably a lion. The monument carried the inscription 'I, Victory, am always with Caesar, of divine descent. ${ }^{39}$ It is quite possible

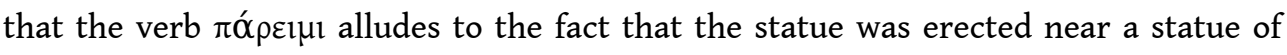
Caesar. Three generations later (after $42 \mathrm{CE}$ ) Kallikrates 'himself repaired and restored the dedications of his ancestors' ${ }^{40}$ Because of the emphatic use of the praenomen aỦ óc ('himself') I suspect that Kallikrates was also the sculptor or the owner of the workshop that did the repair ( uncommon for prominent citizens to be involved in this profession. ${ }^{41}$

The re-dedication of a divine image was a family affair also in Minoa on Anorgos, where a stephanephoros promised to restore a statue of Tyche. His daughter fulfilled the promise and dedicated this statue to Dionysos Minoites (late second century CE). ${ }^{42}$ In the second century CE, a certain Savinianus in Kos found a statue of Aphrodite, an old dedication by Kallistrate, restored it, and 'preserved it for the goddess'. ${ }^{43}$ Unfortunately, in this case the context and Savinianus' relation to the original dedicant are not clear.

These selected examples show that divine statues had bioi, and the examination of the contexts of these bioi may reveal important aspects of the roles played by statues and their perception. Part of this perception is the belief that statues had agency, a subject to which I now turn. 


\section{The emotional agency of divine statues}

21 The agency of lifeless objects, not only statues, mainly originates in the fact that they may provoke unintended responses, usually emotional responses, and so set a series of actions in motion. Malfunctioning computers and cars that refuse to start cause indignation, and people who talk to electronic devices or physically attack them when they remain stubbornly disobedient are not just an invention of comedians. Such an agency is not limited to the statues of gods. Also the statues of mortals may arouse emotions and trigger responses. ${ }^{44}$ It is said e.g. that when the athlete and statesman Theagenes of Thasos died (early fifth century BCE), one of his opponents came every night to his bronze statue and flogged it, until the statue put an end to all that by falling on him and killing him. Recognized as an agent of homicide, the statue was thrown into the sea. When the Thasians were punished with disease, an oracle advised them to return the exiles. The calamity only ended when the last 'exile', Theagenes' statue, was coincidentally caught in the nets of fishermen and brought back to Thasos..$^{45}$ In this and similar narratives, although images appear to act on their own, it is more likely that they were perceived as instruments of avenging spirits or punishing gods. In these cases, agency did not directly derive from them. Things are quite different in the case of statues that provoked erotic desire directed towards the material object. ${ }^{46}$

In order to explain the origin of a mark on one thigh of Praxiteles' Knidian Aphrodite, the author of the Affairs of the Heart narrates the story of a young man who once passionately fell in love with the statue. All day long he would sit facing the goddess with his eyes fixed upon her and whispering words of love, until one night he slipped unnoticed into the temple and attempted to have sex with the statue in the pederastic manner. The marks on the stone were the result of his amorous embraces. Out of his mind, the young man then committed suicide. ${ }^{47} \mathrm{~A}$ similar story was told about another statue of Praxiteles, that of Agathe Tyche in Athens. ${ }^{48}$ The predominant element in these narratives, apart from praising a sculptor's skill, are their paradoxes: instead of arousing delight or awe as images of gods, these statues arouse uncontrolled erotic passion; instead of causing a viewer to admire them as works of art, they made him want to have sex with them, although they were unresponsive, lifeless stones. Such paradoxes explain the genesis and popularity of these narratives.

23 Such anecdotes, despite their lack of historicity, still reflect an important aspect of the lives of divine images: the emotional interaction between worshippers and statues of gods. This subject deserves a systematic study, which cannot be offered here. I will limit myself to a few examples and observations.

Texts related to the communication between worshippers and divinities - prayers, dedicatory inscriptions, oracular inquiries, hymns, etc. - show that this communication was emotionally loaded; depending on the occasion, it was filled with gratitude for past services, hope for future protection, fear of divine power, pride in a successful communication with the divine, or anxiety for the small and big problems of everyday life. ${ }^{49}$ What was the role of statues in this emotional communication?

Both ancient iconography and textual sources attest to the fact that the statue of a divinity was the focal point of the communication between worshipper and divinity. In the case of dedicatory reliefs that show divine figures approached by worshippers it is not always clear whether the divine figures, seated or standing, are to be understood as statues. When worshippers - usually women - appear to kneel before the divine 
figures, we are probably dealing with statues. ${ }^{50} \mathrm{~A}$ terracotta statuette from Korkyra shows a girl near a statue of an enthroned Artemis with raised hands, her small body pressed against the legs of the goddess. ${ }^{51}$ Such a scene probably reflects actual practices, as does a votive relief from Echinos, that represents a woman (a mother or a nurse) approaching a statue of Artemis with an infant girl in her hands. The girl extends her arms towards the goddess, as if trying to touch her statue. ${ }^{52}$ But we do not have to turn to ambiguous images. The textual sources provide enough evidence for worshippers approaching, addressing, and directly interacting with divine images. Already our earliest literary source, the Iliad, presents Theano approaching the statue of Athena, placing a garment on the knees of the statue, and then saying her prayer. ${ }^{53}$ This practice is reflected in ancient iconography ${ }^{54}$ and directly attested by the Brauronian temple inventories from Athens (mid-fourth century BCE). These inventories repeatedly mention the placement of dedicated garments on or near the

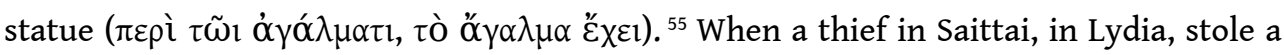
cloak from a bath and believed that he was facing the wrath of the god Mes for his deed, he ultimately brought the garment to the god $(165 \mathrm{CE}) .{ }^{56}$ The relief that decorates this 'confession inscription' shows in the lower level the thief carrying the cloak and on

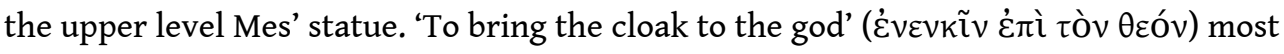
likely means that the thief placed the item in front of the god's statue. Similarly, in the early second century CE in Sagalassos votives were placed on the base of statues of Asklepios and Koronis, in the Nymphaion. ${ }^{57}$ The plinths of these statues have cavities 25 in the case of Asklepios' statue - in which the worshippers placed miniature feet made of bronze. It is difficult to determine whether these votives were representations of healed feet ('anatomical votives') or dedications that symbolized the worshipper's presence near the gods and communication with them..$^{58}$ In either case, the worshippers interacted with the statue in acts of worship. In the context of the statues of healing deities, I should finally mention that in some cases statues were attributed healing properties (see below).

In the light of this evidence, we can understand a peculiar formulation in the inscriptions from the sanctuary of Meter Theon Autochthon at Leukopetra, near Beroia, which record the dedication of slaves. The dedicants delivered to the sanctuary the ownership documents (deeds of sale or other documents); this action is described

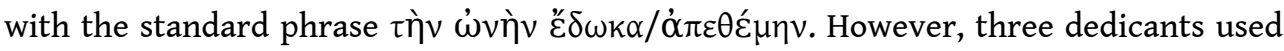
the formula 'I have deposited the deed of sale into the arms of the goddess'. ${ }^{59}$ This expression is attested only in this sanctuary. The deviation from the standard formula

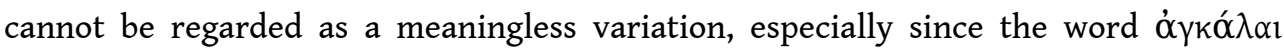
('arms') is emotionally loaded. In epitaphs it refers to an affectionate embrace. It is only once attested in a religious context, in connection with the Ptolemaic princess Berenike, who died still an infant $(238 \mathrm{BCE})$ and whose golden statue was to be carried

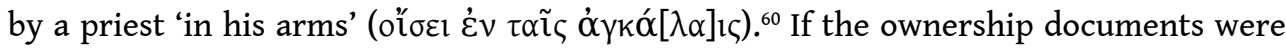
simply deposited in the sanctuary or handed in to the supervisor of the sanctuary, there would have been no reason to create a unique, metaphorical expression. We have to assume that in these cases the worshippers had approached the cult statue of the goddess and placed the document in the arms of the statue in a display of affection. The dedicated slaves were placed under the goddess' motherly protection.

Finally, I should mention the role of statues in a ritual that was expected to fill those who performed it with the fear of god: the oath. Those who swore an oath, i.e. called 
upon them divine punishment in case of perjury, sometimes did not simply invoke a god but also touched the divinity's statue. This is attested through the expression 'to

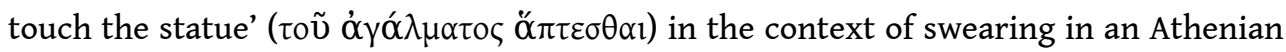
inscription. ${ }^{61}$

\section{Statues filled with divine power}

Interactions of worshippers with statues of gods such as those described in the preceding section inevitably bring us to one of the core questions of research on divine images: is a statue the image of a god or is it the god? The relation between the divinity and its image is a complex subject, as recent research has established. ${ }^{62}$ I will approach the subject by considering the emotional impact of statues, their agency, and the belief that they served as loci and media of divine epiphanies.

In the case of portrait statues of mortals, a statue can be referred to with the name of the depicted individual in the nominative, e.g. $\Phi 1 \lambda \varepsilon ı \tau \tilde{\alpha}_{\varsigma}$ ('[this is] Phileitas'). ${ }^{63}$ But when one pointed to a statue of Demosthenes and said or read 'This is Demosthenes', one did not expect the statue to have Demosthenes' rhetorical abilities, exactly as Magritte's pipe is not a pipe. Similarly, when inscriptions name a divinity or refer to the $\theta \varepsilon \grave{\text { ç }}$ or the $\theta \varepsilon \alpha$, they often mean the divinity's image. For instance, the decree of an Athenian association to honor a certain Dionysios uses the formulation ö $\pi \omega \varsigma \dot{\alpha} \varphi \eta \rho \omega \ddot{\sigma} \sigma \theta \varepsilon \tilde{\imath}$

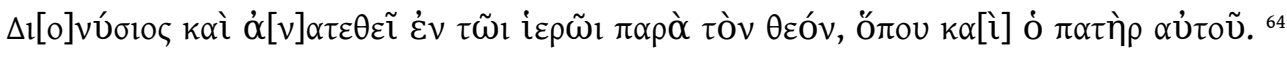
To 'dedicate Dionysos next to the god' means, of course, to dedicate his statue next to the statue of the god. A woman in Mantineia 'at all times served the Kore and joined

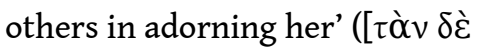

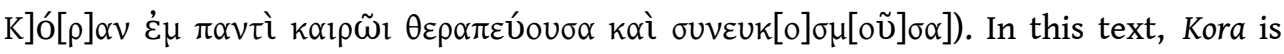
both the goddess, who was being served, ${ }^{65}$ and a statue of the goddess that was being decorated. ${ }^{66}$ In Aphrodisias, the fine for the violation of a grave was to be paid to 'the most sacred goddess Aphrodite', i.e. to Aphrodite's sanctuary, 'for her decoration', i.e. for the decoration of her statue. ${ }^{67}$ These expressions do not imply that the statue had the properties of the goddess. In Greece, divine images were not invested with powers - unlike divine images in the ancient Near East or images used in magic and theurgy. ${ }^{68}$ of course, there were rituals of consecration (see above), but this does not mean that statues of gods were believed to have powers continually and unconditionally.

So, why did worshippers interact with the divine images in the way we saw in the previous section? In the case of mortals, statues were regarded as substitutes of the mortal. They created the illusion of the mortal's presence with the whole emotional 'baggage' that goes with it. ${ }^{69}$ We can see this in the case of a funerary relief from Marathon (second/third century CE). ${ }^{70}$ The image of a young man stands on a rectangular base, flanked by his parents. The mother has put her right arm around the shoulders of her son's statue. Unable to have physical contact with her dead child, at least she could embrace his image. As we have seen, also divine statues had the ability to arouse or intensify emotions. The image psychologically prepared the worshippers to address the divinity, and this was an important factor in the efforts of worshippers to communicate with the gods. But it was not the only factor.

31 Under certain conditions the statues of gods seemed to have possessed an agency that went beyond the emotional agency that I have discussed. They manifested vital functions, they were filled with life in a very real sense, and they acted. ${ }^{71}$ Let us take the 
case of a killing statue, this time not the statue of a mortal such as Theagenes (see above), but the statue of a god. In a poem transmitted among Theocritus' idylls, a beautiful youth remained indifferent towards the suicide of the desperate man who had unsuccessfully pursued him. The heartless boy was punished for his cruelty when a statue of Eros fell upon him and killed him. ${ }^{72}$ Whose agency was at work here? The statue's or the god's?

The answer is provided by Dio of Prusa in a passage often quoted in this context: the statues of gods were 'vessels' ( $\dot{\alpha} \gamma \gamma \varepsilon \tilde{\alpha} \alpha)$ that accommodated divine epiphanies and facilitated the communication between worshipper and divinity. ${ }^{73}$ The statue was medium of a god's epiphany, either during the communication with the worshipper, when the divinity indicated through the movement of the statue that it accepted or rejected the requests of praying mortals,$^{74}$ or when the divinity was enraged and made the statue a medium through which the wrath became manifest. According to Herodotus, when the Athenians attempted to remove the old statues of Damia and Auxesia from Aigina (late sixth century BCE), the images were seen falling on their knees to prevent this. ${ }^{75}$

The gods did not live in their statues, they only visited them. An epigram in the Greek Anthology presents Aphrodite rushing to Knidos to see her statue and wonder where Praxiteles saw her naked and presented her so accurately. ${ }^{76}$ According to Pausanias, Pheidias prayed to Zeus to receive his approval for the statue in Olympia, which the god gave by sending a thunderbolt. ${ }^{77} \mathrm{He}$ would not have done this if the god actually inhabited the statue.

In order to understand the idea that a divine statue manifests a god's power only during a god's epiphany we need to consider a fundamental feature of the divine in Greek religion. ${ }^{78}$ Pagan gods respected the physical laws of time and space. When in the first book of the Odyssey the gods held a council to discuss the return of Odysseus, they could only do so because Poseidon was absent, visiting the Ethiopians and receiving a sacrifice of bulls and sheep. While feasting there, he could not be elsewhere. The Artemision of Ephesos burned on the day Alexander the Great was born, because Artemis was in Pella assisting Olympias in her labor, and not in Ephesos, in her temple. ${ }^{79}$ This idea is also expressed in the hymn of Isyllos at Epidaurus: ${ }^{80}$ The sick child asks the god 'Please have mercy on me!' And the god responds: 'Take courage. I will come to you in due course. You stay here while I ward off disaster from the Spartans.' While in Sparta Asklepios could not be in Epidaurus. One of the healing miracles in Epidaurus reports that the god's sons had to perform surgery because Asklepios was not in Epidaurus. They cut the patient's head off and could not put it back. The patient was saved only when the god returned and finished the job. ${ }^{81}$ Apteros Nike, the wingless personification of victory, is the visual expression of this idea. Without her wings, the goddess of victory must stay in Athens. Numerous divine epithets were created mainly - but not exclusively - in the Hellenistic and Imperial periods precisely in order to indicate that a deity is continually present in a place. ${ }^{82}$

The presence of a god in a place was the result of his personal choice; mortals had to compete to attract his attention. In order to achieve this, they appealed to the gods' senses. They used acoustic signals, such as acclamations, ritual cries, ritual songs, praises, and prayers. ${ }^{83}$ They used visual signals, such as bright clothes, crowns, beautiful animals with gilded horns, and decorated altars, tables, and klinai. They used olfactory signals, such as incense, wine, and thighs burning on the altar. And they 
removed from the place where the divine epiphany was expected anything that might hinder the god's coming, such as sources of pollution and discord. The primary aim of ritual prescriptions and cult regulations concerning purifications, sacrifices, order in sacred places, and the aesthetically pleasing staging of rituals and festivals is to attract the divinity, remove obstacles that might obstruct the communication with the god, and facilitate the epiphany. A god's coming was not to be taken for granted. We recognize this in Kallimachos' hymn to Apollo, when the poet describes the anxiety of the worshippers anticipating the god's imminent arrival on Delos. ${ }^{84}$ In the first verses the poet observes the movement of the sacred palm tree and the flight of the birds; these are signs that the god is approaching. With the sacred cry $\varepsilon \dot{\nu} \varphi \eta \mu \varepsilon \tilde{\tau \varepsilon}$ ('use good language') he then urges the worshippers to use pious words, avoiding any articulate or inarticulate sound which might disturb communication with the god and present an obstacle to his coming. Even Achilles' mother, Thetis, eternally mourning for her son's death, has to postpone her lament as soon as she hears this ritual cry. ${ }^{85}$

Precisely because a god could not be in two places at the same time, he could not continually inhabit his statue. He manifested his power through his statue during an epiphany. A few examples may illustrate this. When the Ephesians sent an embassy to Emperor Caracalla, 'Artemis, the ancestral goddess, was leading the embassy', as a decree states. ${ }^{86}$ As the statue of Artemis was carried by the envoys, Artemis was thought to be present through her statue.

As a privileged medium of epiphany, the divine image has to be periodically prepared to receive the divinity. This is the aim of the statue's ritual treatment, the removal of stain and its adornment. In an inscription from Olbia (ca. 200-210 CE), the washing of the statue of Zeus Olbios is directly connected with the manifestation of divine power. The decree praises the local statesman and benefactor Kallikrates: ${ }^{87}$

When he became priest of Zeus Olbios, the god who presides over our city, he washed the god in a pure manner, and praying for a good combination of winds he achieved prosperity.

The epiphany of a divinity through a statue could be staged in various ways, e.g. with the use of glass and gold that reflected light, with the use of perfumes that appealed to the senses, or with windows that let raking light into the temple..$^{88} \mathrm{As}$ an agent of divine power the divine image was thought to respond to prayers, ${ }^{89}$ to avert evil, and to have healing powers.

Longus presents Daphnis prostrating himself in front of the statue of the Nymphs and Pan, praying, and promising sacrifices. ${ }^{90}$ During the devastating pestilence of the midsecond century CE a city in Asia Minor, probably Sardis, received an oracle of Apollo Klarios advising its inhabitants to bring a statue of Artemis from Ephesos, set it up in the temple, and worship the goddess with hymns, sacrifices, praises, and choral dances of girls, 'in order that she might always be to you an unfailing helper'. ${ }^{91}$ The physical presence of Artemis' statue in combination with rituals resulted in the presence of her

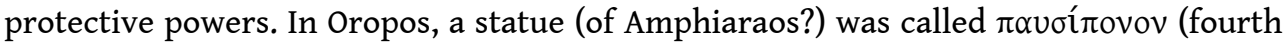
century $\mathrm{BCE}$ ), a statue that made pains stop..$^{92}$ The story is told that the wife of the Spartan king Ariston used to bring her ugly daughter to the sanctuary of Helena; the girl prayed in front of Helena's statue and finally grew to become a beautiful woman. ${ }^{93}$

In some cases, divine images had emotive power only by symbolically warning the viewer of the possible consequences of his actions. A Greek-Latin bilingual epigram on 
the base of an ithyphallic Priapos at Acireale (third century CE) makes clear what thieves are to expect: ${ }^{94}$

Samios erected me, a Priapus, to watch on both sides, lest thieves from the city or poor people from Akis enter (this estate), so that I may save for him the produce.

For to the desecrators I am showing my penis erect, this thick one.

An inscription under a statue of Athena, represented in full armor (Stratonikeia, undated) threatened evil persons with divine punishment: 'Against the evil my hand is merciless; but if someone who is pure honors me, I hold this spear above him (in his protection) .95

\section{Conclusions}

42 In the complex subject that I have approached mainly from the perspective of documentary sources, generalizations are likely to be wrong. Ancient conception must have varied, depending on time, place, and the nature of the cult. Most of the evidence presented in the paper - but also most of the surviving documentary evidence - dates to the Hellenistic and Imperial periods, i.e. periods in which we may expect influences from the Egyptian religion and Oriental cults. This makes a distinction between early traditions and innovations difficult. But such methodological issues left aside, one aspect of the life of statues must have existed in earlier Greek worship: the emotive power of images of gods.

The emotional impact of statues in Greek culture is certainly connected with their materiality and physical presence. As three-dimensional life-size, or close to life-size, representations they are as close as one can get to the 'real thing'. Skillful artists could even create the illusion that a statue was alive. ${ }^{96}$ These properties of statues invited people to interact with them, as anecdotes, images, and documentary sources show. Under certain circumstances statues, not only the statues of gods, appeared to have agency. They were believed to kill, heal, or punish; they presented the physical symptoms of life; they aroused emotions that could trigger actions or create the illusion that a direct communication with the statue was possible.

The statues of gods were part of a dynamic interaction between images and viewers. They were washed and perfumed, anointed, greeted, offered food, touched, kissed, raped, and castrated; women dressed them, men carried them in processions or carried them away, birds left their dung on them, enemies captured them; they were attacked, destroyed, burned, repaired, hidden, or buried. Statues gained a life precisely through this continual interaction with humans.

Affective responses to statues were part of this life. The divine images were manipulated as visual stimuli of an emotional interaction with the divine. The statues of gods were not gods. But they had a very important role in the competitive and very fragile communication between mortals and immortals who were not omnipresent. They displayed tremendous emotional power and, when the gods decided to reveal their power - in festivals or in every-day situations -, they were a preferred medium of divine epiphany. 


\section{BIBLIOGRAPHY}

N.E. AKYÜREK şAHIN, “Bilecik'ten Bir Grup Zeus Büstü ve Zeus Bronton”, Gephyra 11 (2014), p. 121171.

A. AVAGIANOU, Sacred Marriage in the Rituals of Greek Religion, Bern, 1991.

Z. BAHRANI, "Assault and Abduction: the Fate of the Royal Image in the Ancient Near East", Art History 18.3 (1995), p. 363-382.

M.-F. BASLEZ, “Les thérapeutes de Délos et d'ailleurs : l'apport de l'épigraphie délienne à l'histoire des communautés religieuses à l'époque hellénistique et romaine”, in C. BALANDIER, C. CHANDEZON (eds.), Institutions, sociétés et cultes de la Méditerranée antique. Mélanges d'histoire ancienne rassemblés en l'honneur de Claude Vial, Bordeaux, 2014, p. 109-131.

A. BERNAND, La prose sur pierre dans l'Égypte hellénistique et romaine, Paris, 1992.

P. BERNARD, "Vicissitudes au gré de l'histoire d'une statue en bronze d'Héraclès entre Séleucie du Tigre et la Mésène”, JS (1990), p. 3-68.

S. BETTINETTI, La statua di culto nella pratica rituale greca, Bari, 2001.

G.W. BOWERSOCK, “La Mésène (Maisân) antonine”, in T. FAHD (ed.), L'Arabie préislamique et son environemment historique et culturel. Actes du Colloque du Strasbourg, Strasbourg, 1989, p. 159-168.

J.N. BREMMER, “The Agency of Greek and Roman Statues”, Opuscula 6 (2013), p. 7-21.

P.-A. BRODER, "La manipulation des images dans les processions en Grèce ancienne", in Image et religion dans l'antiquité gréco-romaine. Actes du colloque de Rome, 11-13 décembre 2003, Naples, 2008, p. 121-135.

W. BURKERT, "Katagógia-Anagógia and the Goddess of Knossos", in R. HÄGG, N. MARINATOS, G. NORDQUIST (eds.), Early Greek Cult Practice. Proceedings of the Fifth International Symposium at the Swedish Institute at Athens, 26-29 June, 1986, Stockholm, 1988, p. 81-87.

H.-U. CAIN, "Hellenistische Kultbilder. Religiöse Präsenz und museale Präsentation der Götter im Heiligtum und beim Fest”, in M. WÖRRLE, P. ZANKER (eds.), Stadtbild und Bürgerbild im Hellenismus, Munich, 1995, 115-130.

B. CASEAU, "Religious Intolerance and Pagan Statuary", in L. LAVAN, M. MULRYAN (eds.), The Archaeology of Late Antique 'Paganism', Leiden, 2011, p. 479-502.

A. CHANIOTIS, "Ritual Dynamics: The Boiotian Festival of the Daidala", in H.F.J. HORSTMANSHOFF, H.W. SINGOR, F.T. VAN STRATEN, J.H.M. STRUBBE (eds.), Kykeon. Studies in Honour of H.S. Versnel, Leiden, 2002, p. 23-48.

-, “Acclamations as a Form of Religious Communication", in H. CANCIK, J. RÜPKE (eds.), Die Religion des Imperium Romanum. Koine und Konfrontationen, Tübingen, 2009a, p. 199-218.

-, "Le visage humain des rituels : expérimenter, mettre en scène et négocier les rituels dans la Grèce hellénistique et l'Orient romain", Annuaire de l'École pratique des hautes études (EPHE), Section des sciences religieuses 116 (2009b), p. 171-178.

-, "Megatheism: The Search for the Almighty God and the Competition of Cults", in S. MITCHELL, P. VAN NUFFELEN (eds.), One God: Pagan Monotheism in the Roman Empire, Cambridge, 2010, p. 112-140. 
-, "Emotional Community through Ritual. Initiates, Citizens, and Pilgrims as Emotional Communities in the Greek World," in A. CHANIOTIS (ed.), Ritual Dynamics in the Ancient Mediterranean: Agency, Emotion, Gender, Representation, Stuttgart, 2011, p. 264-290.

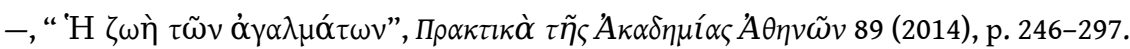

-, "The Life of Statues: Emotion and Agency", in D. CAIRNS, D.P. NELIS (eds.), Emotions in the Classical World: Methods, Approaches and Directions, Stuttgart, 2017a, 143-158.

-, "Emotions in Sacred Spaces: Hope, Fear, and Gratitude and the Foundation of Piety", in A. CHANIOTIS, N. KALTSAS, I. MYLONOPOULOS (eds.), A World of Emotions: Greece, 700 BC-200 AD, New York, 2017b, 192-203.

P. CHARNEUX, “Sur un décret des forgerons d'Argos", BCH 116 (1992), p. 335-343.

P. CHRISTODOULOU, "Les reliefs votifs du sanctuaire d'Isis à Dion", in L. BRICAULT, R. VEYMIERS, Bibliotheca Isiaca II, Bordeaux, 2011, p. 11-22.

A. coRso, “Ancient Greek Sculptors as Magicians", Quaderni Ticinesi. Numismatica e Antichità Classiche 28 (1999), p. 97-111.

F. DAKORONIA, L. GOUNAROPOULOU, “Artemiskult auf einem neuen Weihrelief aus Achinos bei Lamia”, $\operatorname{MDAI}(A) 107$ (1992), p. 217-227.

G.I. DESPINIS, “Die Kultstatuen der Artemis in Brauron”, MDAI(A) 119 (2004), p. 261-315.

L. DEUBNER, Attische Feste, Berlin, 1932.

M.W. DICKIE, “Who Were Privileged to See the Gods?”, Eranos 100 (2002), p. 109-127.

E.R. DoDDS, The Greeks and the Irrational, Berkeley/Los Angeles, 1951.

A.A. DONOHUE, Xoana and the Origins of Greek Sculpture, Atlanta, 1988.

C.A. FARAONE, "Binding and Burying the Forces of Evil: the Defensive Use of 'Voodoo Dolls' in Ancient Greece", Classical Antiquity 10 (1991), p. 165-205.

-, Talismans and Trojan Horses: Guardian Statues in Ancient Greek Myth and Ritual, New York/Oxford, 1992.

J.A. FRANCIS, "Living Icons: Tracing a Motif in Verbal and Visual Representation from the Second to the Fourth Centuries C.E.", AJPh 124 (2003), p. 575-600.

B. GLADIGOW, "Präsenz der Bilder - Präsenz der Götter. Kultbilder und Bilder der Götter in der griechischen Religion”, Visible Religion 4/5 (1985/86), p. 114-133.

F. GRAF, “An Oracle against Pestilence from a Western Anatolian Town”, ZPE 92 (1992), p. 267-279.

-, "Ritual Restoration and Innovation in the Greek Cities of the Roman Empire", in A. CHANIOTIS (ed.), Ritual Dynamics in the Ancient Mediterranean: Agency, Gender, Emotion, Representation, Stuttgart, 2011, p. 105-117.

M. GUGGISBERG, "Lebendige Götter. Zum Verhältnis von Gottheit und Gottesbild im antiken Griechenland", in M.M. LuISELLI, J. MOHN, S. GRIPENTROG (ed.), Kult und Bild. Die bildliche Dimension des Kultes im alten Orient, in der Antike und in der Neuzeit, Würzburg, 2013, p. 67-89.

K. GUTZWILLER, “Gender and Inscribed Epigram. Herennia Procula and the Thespian Eros", TAPhA 134 (2004), p. 383-418. 
S. HAGEL, K. TOMASCHITZ, Repertorium der westkilikischen Inschriften, nach den Scheden der Kleinasiatischen Kommission der Österreichischen Akademie der Wissenschaften, Vienna, 1998 (Ph.-Hist. Klasse, Denkschr. Band 265; Ergänzungsbände zu den Tituli Asiae Minoris, 22).

G.L. HERSEY, Falling in Love with Statues: Artificial Humans from Pygmalion to the Present, Chicago, 2009.

F. HÖLSCHER, "Gods and Statues. An Approach to Archaistic Images in the Fifth Century BCE”, in MYLONOPOULOS (2010), p. 105-120.

T. HÖLSCHER, La vie des images grecques. Sociétés de statues, rôles des artistes et notions esthétiques dans l'art grec ancien, Paris, 2015.

A. INVERNIZZI, “Héraclès à Séleucie du Tigre”, RA (1989), p. 65-113.

M.H. JAMESON, “Theoxenia”, in R. HÄGG (ed.), Ancient Greek Cult Practice from the Epigraphical Evidence. Proceedings of the Second International Seminar on Ancient Greek Cult, Organized by the Swedish Institute at Athens, 22-24 November 1991, Stockholm, 1994, p. 35-57.

C.P. JONES, “Zeus Anabatênos and Zeus Kersoullos”, ZPE 180 (2012), p. 233-236.

S.C. JONES, "Statues that Kill and the Gods who Love Them", in K.J. HARTSWICK, M.C. SURGEON (eds.),

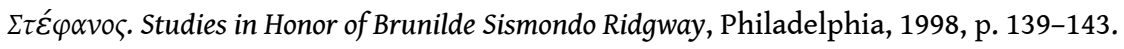

R. KASSEL, “Dialoge mit Statuen”, ZPE 51 (1983), p. 1-12.

C.M. KEESLING, "Vor klassischem Hintergrund. Zum Phänomen der Wiederverwendung älterer Statuen auf der Athener Akropolis als Ehrenstatuen für Römer", in R. KRUMEICH, C. WITSCHEL (eds.), Die Akropolis von Athen im Hellenismus und in der römischen Kaiserzeit, Wiesbaden, 2010, p. 329-398.

D. KNOEPFLER, “Cupido ille propter quem Thespiae visuntur. Une mésaventure insoupçonnée de l'Eros de Praxitèle et l'institution du concours des Erôtideia”, in D. KNOEPFLER et al. (eds.), Nomen Latinum. Mélanges de langue, de littérature et de civilisation latines offerts au professeur André Schneider à l'occasion de son départ à la retraite, Neuchâtel, 1997, p. 17-39.

T.M. KRISTENSEN, Making and Breaking the Gods: Christian Responses to Pagan Sculpture in Late Antiquity, Aarhus, 2013.

J. MA, Statues and Cities. Honorific Portraits and Civic Identity in the Hellenistic World, Oxford, 2013.

S. MÄGELE, "Ein besonderer Ort für Votive: Anmerkungen zu einem ungewöhnlichen Befund an drei Statuen aus einem Nymphäum in Sagalassos", MDAI(I) 55 (2005), p. 289-307.

J. MARCADÉ, Au Musée de Délos. Étude sur la sculpture hellénistique en ronde bosse découverte dans l'île, Paris 1969.

S. MONTEL, "Espaces, environnement architectural et rituels autour des statues dans les sanctuaires grecs", RHR 231 (2014), p. 729-744.

J. MYLONOPOUlos (ed.), Divine Images and Human Imaginations in Ancient Greece and Rome, Leiden, 2010 .

-, "Divines Images versus Cult Images: An Endless Story about Theories, Methods, and Terminologies", in MYLONOPOULOS (2010), p. 1-19.

I. PETROVIC, “The Life Story of a Cult Statue as an Allegory. Kallimachos' Hermes Perpheraios”, in MYLONOPOULOS (2010), p. 205-224.

G. PETZL, Die Beichtinschriften Westkleinasiens, Bonn, 1994 (Epigraphica Anatolica, 22). 
V. PIRENNE-DELFORGE, "Des marmites pour un méchant petit hermès! ou comment consacrer une statue", in S. ESTIENNE et al. (eds.), Image et religion dans l'Antiquité gréco-romaine, Naples, 2008 p. $103-110$.

-, “Greek Priests and 'Cult Statues': In How Far Are They Unnecessary?”, in MYLonopoulos (2010), p. 121-141.

D.S. POTTER, “The Inscriptions on the Bronze Herakles from Mesene: Vologeses IV's War with Rome and the Date of Tacitus' Annales", ZPE 88 (1991), p. 277-290.

E.R. REEDER, Pandora. Women in Classical Greece, Baltimore, 1995.

E. RICE, The Grand Procession of Ptolemy Philadelphus, Oxford, 1983.

G.M. ROGERS, The Sacred Identity of Ephesos. Foundation Myths of a Roman City, London, 1991.

T. SCHEER, Die Gottheit und ihr Bild. Untersuchungen zur Funktion griechischer Kultbilder in Religion und Politik, Munich, 2000.

J.L. SHEAR, "Reusing Statues, Rewriting Inscriptions, and Bestowing Honours in Roman Athens", in Z. NEWBY, R. LEADER-NEWBY (eds.), Art and Inscriptions in the Ancient World, Cambridge, 2007, p. 221246.

R.R.R. SMITH, "Statue Life in the Hadrianic Baths at Aphrodisias, CE 100-600: Local Context and Historical Meaning", in F.A. BAUER, C. WITSCHEL (eds.), Statuen in der Spätantike, Wiesbaden, 2007, p. 203-235.

-, "Defacing the Gods at Aphrodisias", in B. DIGNAS, R.R.R. SMITH (eds.), Historical and Religious Memory in the Ancient World, Oxford, 2012, p. 283-326.

-, C.H. HALLETT, “Troilos and Achilles: A Monumental Statue Group from Aphrodisias”, JRS 105 (2015), p. 124-182.

D.T. STEINER, Images in the Mind. Statues in Archaic Greek Literature and Thought, Princeton, 2001.

P. STEWART, “The Destruction of Statues in Late Antiquity”, in R. MILES (ed.), Constructing Identities in Late Antiquity, London, 1999, p. 159-189.

H. TAEUBER, “Ein Inschriftenfragment der Polydamas-Basis von Olympia”, Nikephoros 10 (1997), p. 235-243.

F.T. VAN STRATEN, “Did the Greeks Kneel Before their Gods?”, BABesch 49 (1974), p. 159-189.

A.-M. vÉRILHAC, “Artémis à Échinos”, in C. BALANDIER, C. CHANDEZON (eds.), Institutions, sociétés et cultes de la Méditerranée antique. Mélanges d'histoire ancienne rassemblés en l'honneur de Claude Vial, Bordeaux, 2014, 133-146.

H.S. VERSNEL, Coping with the Gods: Wayward Readings in Greek Theology, Leiden, 2011.

P. ZANKER, “Der Boxer”, in L. GIULIANI (ed.), Meisterwerke der antiken Kunst, Munich, 2003, p. 28-49.

\section{NOTES}

1. http://www.news.com.au/world/man-sets-self-afire-on-lenin-statue/story-

fn6sb9br-1226081695395\#ixzz1m8Lp4rgf (accessed on 10 February 2012).

2. PIRENNE-DELFORGE (2010), p. 126-141.

3. https://hellopoetry.com/poem/1618156/she-stood-like-a-statue/. 
4. KASSEL (1983), p. 1f.; STEINER (2001), p. 136.

5. Corpus Paroemiographorum Graecorum I, p. 347 Leutsch-Schneidewin.

6. E.g. SMIth (2007); MYLONOPOULOS (2010), p. 12-18; PETROVIC (2010); CHANIOTIS (2014) and (2017a).

Cf. HÖLSCHER (2015): 'life of images'.

7. CHANIOTIS (2017a).

8. BREMMER (2013) refers to this expression of life as 'agency'.

9. I use the term 'epiphany' to designate any manifestation of divine presence and power, from an earthquake to an epiphanic dream.

10. PIRENNE-DELFORGE (2008).

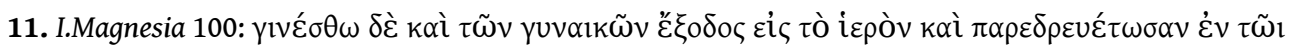

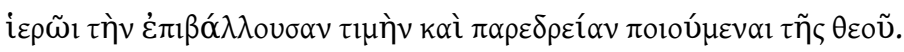

12. E.g. I.Ephesos 3436; I.Magnesia 179; SEG 48, 1769; cf. MA (2013), p. 246.

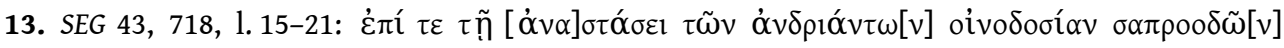

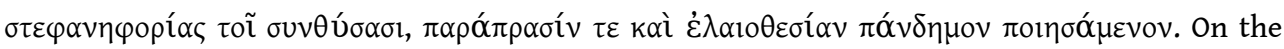
dedication of emperors on their birthday, which was celebrated as a festival, see e.g. I.Cret. I, xviii 23.

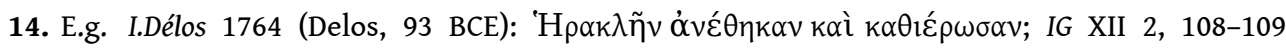

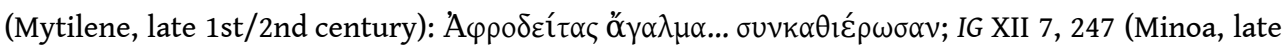
2nd century CE): $\kappa \alpha \theta i \varepsilon \rho \omega \theta \theta \eta$ (statue of Tyche); I.Pergamon II (Pergamon, Imperial period):

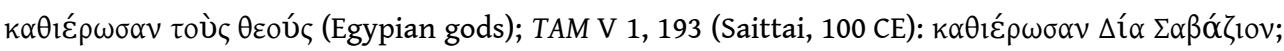

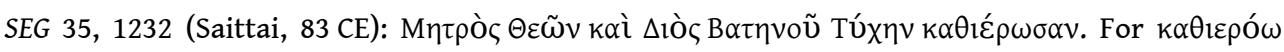
used for statues of the personified Demos see IGR IV 792 (Apameia, 45 CE); IAph2007 12, 922 (Aphrodisias, 3rd century CE).

15. On the ritual treatment of cult statues see SCHEER (2000), p. 54-66; BETTINETTI (2001); STEINER (2001), p. 105-120; DESPINIS (2004), p. 301f.; MONTEL (2014).

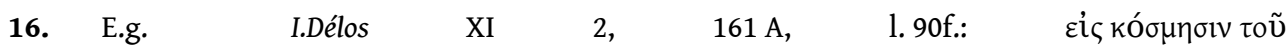

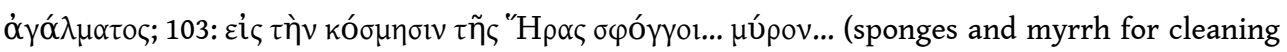
and anointing; $279 \mathrm{BCE}$ ). See also MARCADÉ (1970), p. 98-101. Other examples: IG V 2, 265

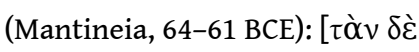

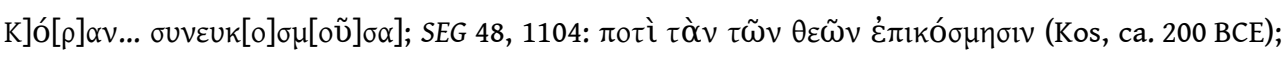

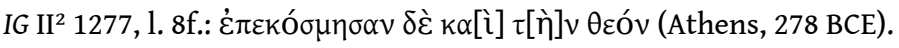

17. See AVAGianou (1991), p. 45-58, for the role of a divine image ( $\beta p \varepsilon ́ \tau \alpha \varsigma)$ of Hera in a ritual of sacred marriage in Samos. The evidence for a sacred marriage involving a statue of Hera in Argos (ibid. 36-45) is less conclusive. Images were also involved in the Boiotian festival Daidala, which in Pausanias' times was perceived as a sacred marriage (ibid., p. 59-68) but whose origins are far more complex; see CHANIOTIS (2002).

18. E.g. BURKERT (1988). For the statue of Dionysos Eleuthereus at the Athenian Dionysia see DEUBNER (1932), p. 139.

19. JAMESON (1994).

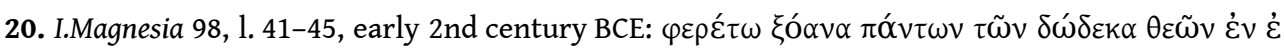

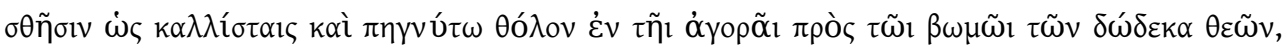
$\sigma \tau \rho \omega v u ́ \tau \omega \delta \grave{\varepsilon} \kappa \alpha i ̀ ~ \sigma \tau \rho \omega \mu v \grave{\alpha} \varsigma \tau \rho \varepsilon \tilde{\imath} \varsigma \dot{\omega} \zeta$ $\kappa \alpha \lambda \lambda i ́ \sigma \tau \alpha \zeta$.

21. Alexandria: Athenaios, V, 196a-203b. Ephesos: I.Ephesos 27 A; ROGERS (1991); GRAF (2011), p. 110-115. Statues in processions: BRODER (2008).

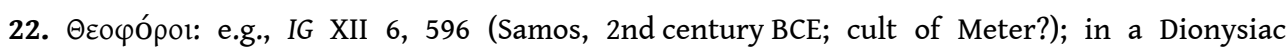
association: IGUR I, 160 (Rome, ca. $150 \mathrm{CE}$ ). The carrying of divine statues and sacred objects is

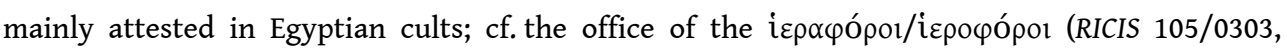
105/0895, 113/0526, 113/0530, 113/0557, 113/0574, 202/1007, 205/0104, 301/1202). 
23. TAM III 1,136 (Termessos, 1st/2nd century):

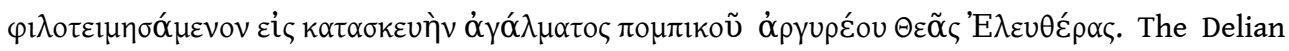
accounts of 279 BCE mention repairs of the cart on which the statue of Dionysos was carried: IG IX

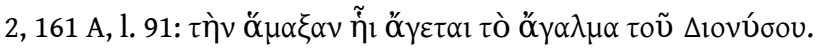

24. I.Stratonikeia $1101=$ LSAM 69.

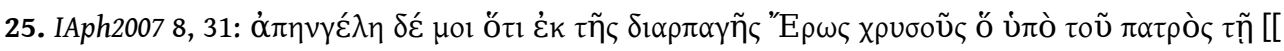

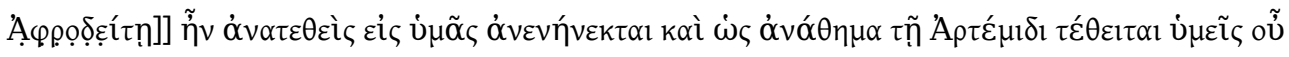

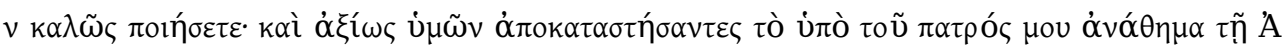

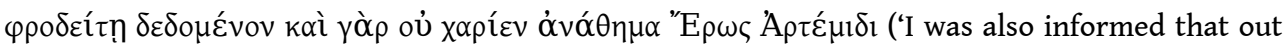
of the loot a golden Eros, which had been dedicated by my father to Aphrodite, has been brought to you and set up as an offering to Artemis. You will do well and worthily of yourselves if you restore the offering which my father gave to Aphrodite. In any case Eros is not a suitable offering for Artemis').

26. KNOEPFLER (1994); cf. GUTZWILLER (2004), 386f.

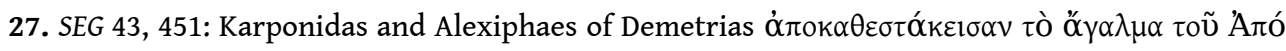

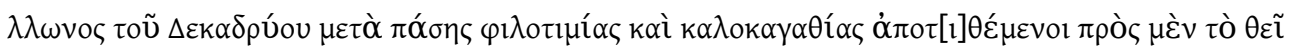

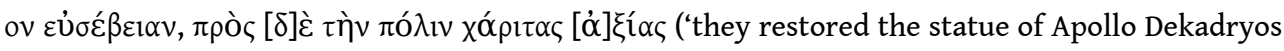
with a lot of love of honor and virtue showing piety towards the divinity and a worthy favour towards the city').

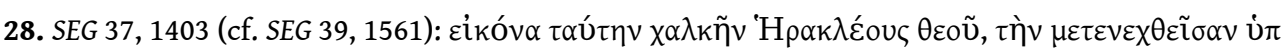

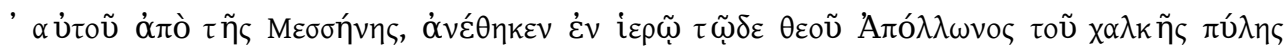
$\pi \rho 0 \kappa \alpha \theta \eta \mu \varepsilon ́ v o u$. See BOWERSOCK (1989); INVERNIZZI (1989); BERNARD (1990); POTTER (1991).

29. E.g. BAHRANI (1995).

30. CHARNEUX (1992).

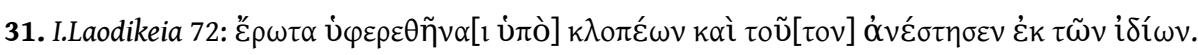

32. On the (selective) destruction of statues of gods in Late Antiquity see STEWART (1999); SMITH (2012); KRISTENSEN (2013). Hidding statues of gods: CASEAU (2011).

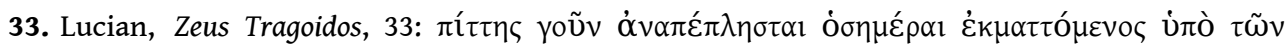
$\dot{\alpha} v \delta \rho 1 \alpha v \tau \circ \pi \circ i \tilde{\omega} v$.

34. Iamblichos, Life of Pythagoras, 28, 143.

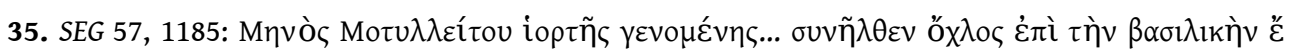

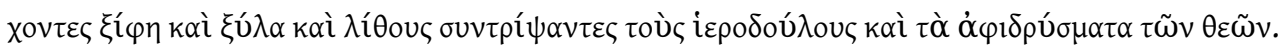

36. SHEAR (2007); KEESLING (2010).

37. SMITH - HALLETT (2015).

38. I.Milet I 7, 269.

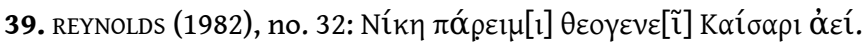

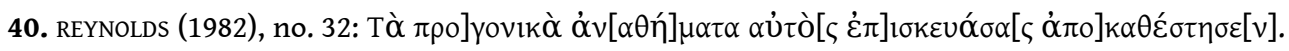
The same Kallikrates also restored honorific statues of his ancestors: REYNOLDS (1982), no. 29.

41. E.g. IAph2007 11, 16 (Adrastos Hierax); IAph2007 1160 (Dionysios); IAph2007 12, 526 (Apollonios).

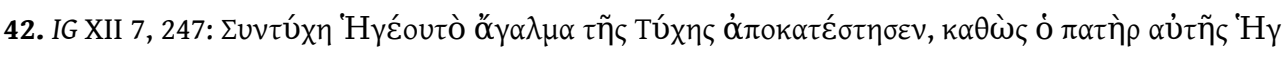

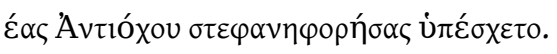

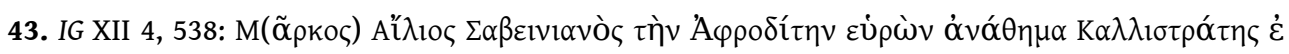

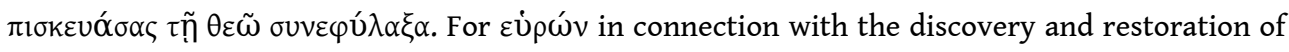

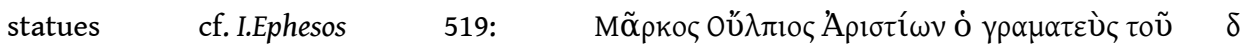

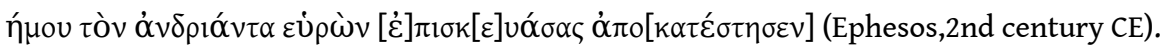

44. CHANIOTIS (2017a).

45. Pausanias, VI, 11; discussion and further examples: CHANIOTIS (2017a), p. $149 f$. 
46. CORSO (1999), p. 102-104; STEINER (2001), p. 186-207; HERSEY (2009); MYLONOPOULOS (2010), p. 1-3; CHANIOTIS (2017a), p. $153 \mathrm{f}$.

47. Pseudo-Lucian, Amores, 13-16.

48. Aelian, Varia historia IX, 39.

49. CHANIOTIS (2017b).

50. VAN STRATEN (1974).

51. VÉRILHAC (2014), p. 141; cf. REEDER (1995), p. 312, fig. 93.

52. DAKORONIA - GOUNAROPOULOU (1992). Recent discussion: VÉRILHAC (2014).

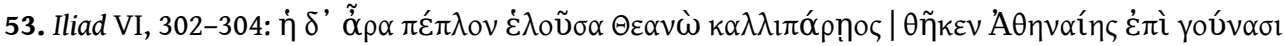

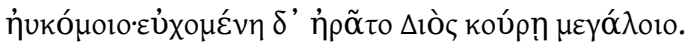

54. See GUGGISBERG (2013), p. 69, for the representation of an enthroned goddess with a peplos on her knees, from South Italy.

55. IG II ${ }^{2}$ 1514, 1. 41-43; 1523, II, 1. 27f.; 1524, II, 1. 202-207.

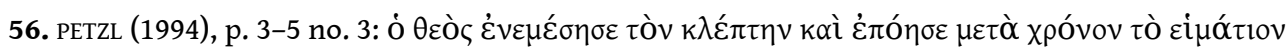

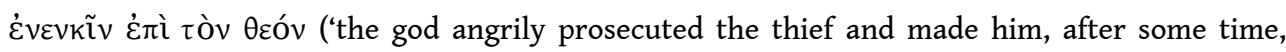
bring the garment to the god').

57. MÄGELE (2005).

58. Cf. the 'footprints' dedicated to Egyptian deities in Greek sanctuaries: e.g. IG XII 2.1, 120 (Thessalonike); I.Beroia 34 and 35 (Beroia); christodoulou (2011) (Dion).

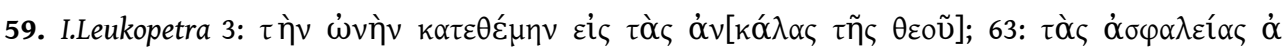

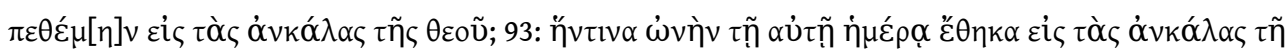
$\varsigma \theta \varepsilon \circ \tilde{\text {. }}$

60. CHANIOTIS (2011), p. 278f. The statue of Berenike: BERNAND (1992), no. 8, 1. $50 \mathrm{f}$.

61. IG I3 254, 1.12 (5th century BCE).

62. A selection of recent discussions: JONES (1998); GLADIGOW (1985/86); SCHEER (2000), p. 44-130; STEINER (2001), p. 79-134; FRANCIS (2003); HÖLSCHER (2007), p. 117f.; GUGGISBERG (2013).

63. IG XIV 2486; SEG 58, 1130 (2nd century CE). On the use of the nominative on honorific statues see MA (2013), p. 24-30.

64. IG $\mathrm{II}^{2} 1326,1.45-47$.

65. On the meaning of $\theta \varepsilon \rho \alpha \pi \varepsilon i^{\prime} \alpha$ and $\theta \varepsilon \rho \alpha \pi \varepsilon U ́ \omega$ see BASLEZ (2014).

66. IG V 2, 265 (64-61 BCE). More examples in notes 16, 43, and 59.

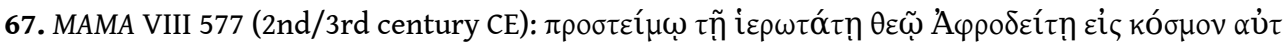
กิऽ.

68. DODDS (1951), p. 291-295; DONOHUE (1988), p. 152f., 158f.; STEINER (2001), p. 114-120.

69. STEINER (2001), p. 145-151.

70. SEG 46, 286. CHANIOTIS (2014), p. 282.

71. The 'agency' of statues in this sense has been recently surveyed by BREMMER (2013).

72. Ps.-Theocritus, 23.

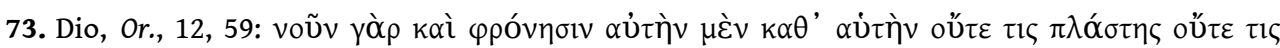

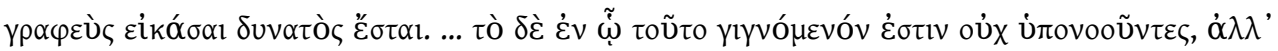

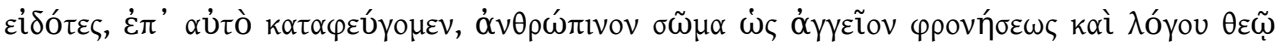

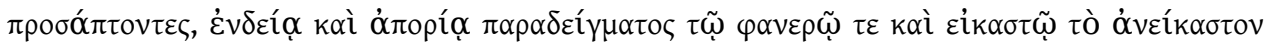

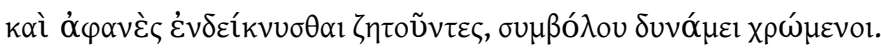

74. Iliad VI, 311; Aeschylus, Agamemnon, 519-520; Euripides, Iphigeneia in Tauris, 1167; Lucian, Lexiphanes, 12. See also STEINER (2001), p. 134, 175f., and 182; BREMMER (2013), p. 8 f.

75. Herodotus, V, 86, 3. For similar stories see STEINER (2001), p. 182; BREMMER (2013), p. 10; CHANIOTIS (2017a), p. $150 f$.

76. Anth. Pal. XVI, 160; cf. XVI, 162. 
77. Pausanias, $\mathrm{V}, 11,9$.

78. CHANiOTIS (2009), p. 199f. I cannot discuss here the question how the numerous epithets and the polyonymy of gods relate to the 'identity' of a god; see VERSNEL (2010), p.60-87. At least in certain cases, multiple epithets imply multiple gods. E.g., an inscription in Hadrianoi reports that Zeus Anabatenos dedicated a statue to Zeus Kersoullos (SEG 59, 148, 2nd/3rd century CE). See JONES (2012) with further examples. This implies that these are two different gods; presumably, Zeus Anabatenos could have an epiphany in one place, while Zeus Kerspoullos had his in another at the same time. And yet, another inscription of the same period from the border of Phrygia and Bithynia (AKYÜREK şAHIN [2014], p. 132f. no. 3) implies that Zeus Bronton, Zeus Karpodotes, and

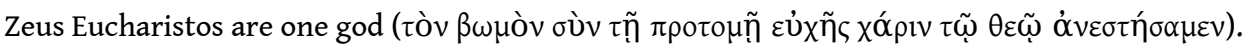

79. Plutarch, Alexander, 3,6 .

80. IG IV ${ }^{2} 1,128,1.64-71$.

81. IG IV ${ }^{2} 1,122,1.10-19$.

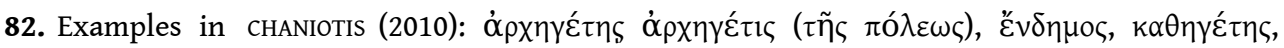

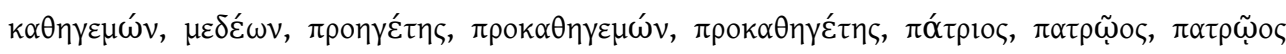

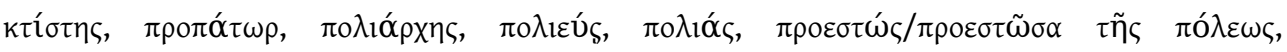

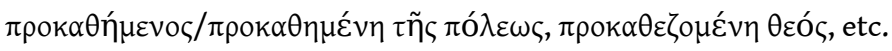

83. CHANIOTIS (2009b).

84. DICKIE (2002).

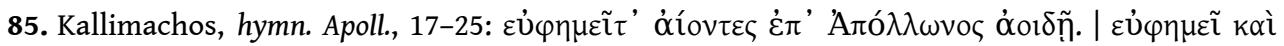

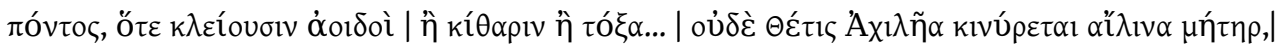

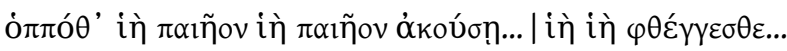

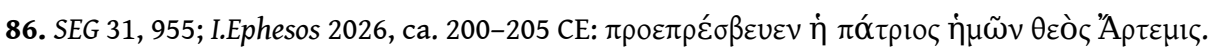

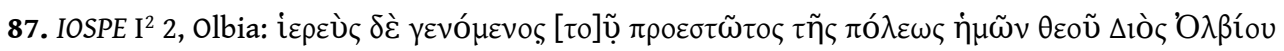

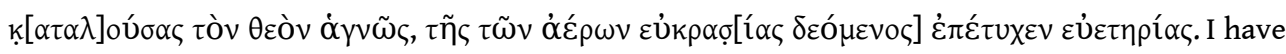

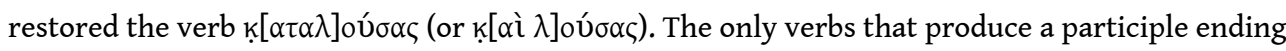

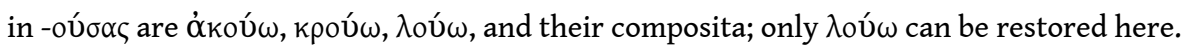

88. STEINER (2001), p. 101f.; cf. CAIN (1995); CORSO (1999), p. 101.

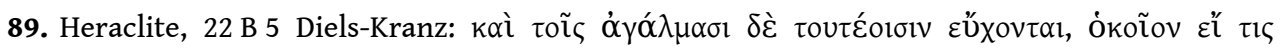

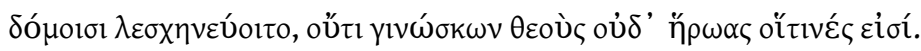

90. Longus, Daphnis and Chloe II, 24, 1-2.

91. GRAF (1992). For a similar recommendation of the oracle of Klaros to Syedra (erection of statues of Hermes and Dike punishing Ares, first century BCE) see SEG 41, 1411; MERKELBACH STAUBER, SGO I n ${ }^{\circ}$ 18/19/01: FARAONE (1991) and (1992), p. 72.

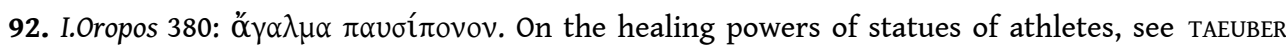
(1997); ZANKER (2003), p. 48f.

93. Herodotus, VI, 61.

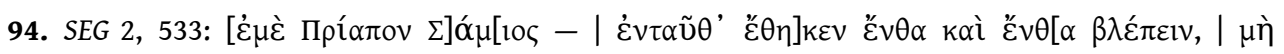

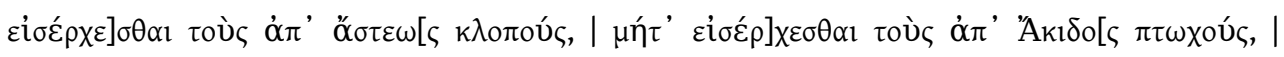

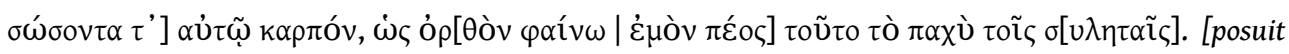
hic] me Samius utroque in[spicientem, / meum en]ormem penem ut osten[dam furibus].

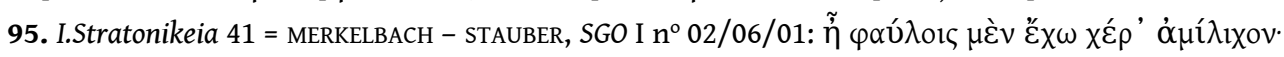

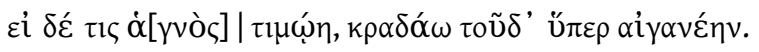

96. See e.g. the epigrams written about Myron's cow: Anth. Pal. IX, 713-742 and 793-798. Cf. e.g.

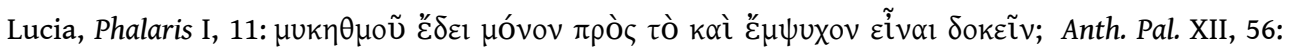

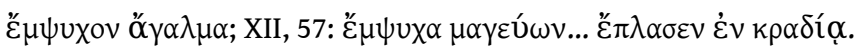




\section{ABSTRACTS}

Statues of gods in Greek culture had lives, both metaphorically and literally. The statues of gods had complex ritual lives. They had biographies (bioi); they travelled; they were subject to peripeties (destruction, repairs, re-dedication); and they suffered violence. Although they were not an indispensable element of worship, the images psychologically prepared the worshippers to address the divinity, and this was an important factor in the efforts of worshippers to communicate with the gods. Through the arousal of emotions they provoked actions that were beyond or contrary to human intentions; in this sense, they had agency. Finally, under certain conditions they were perceived as fulfilling vital functions. Since Greek gods could not be in two places at the same time, they could not continually inhabit their statues. But they manifested their power through the statue during an epiphany. A statue was a receptacle (ankeion) of a god and medium of epiphany.

Dans la culture grecque, les statues de dieux avaient une vie, d'un point de vue tant métaphorique que littéral. Les statues de dieux avaient des vies rituelles complexes. Elles avaient une biographie (bios), elles voyageaient, elles connaissaient divers aléas (destruction, réparation, nouvelle dédicace), et elles subissaient des violences. Même si elles n'étaient pas des éléments indispensables au culte, les images préparaient psychologiquement les fidèles à s'adresser à la divinité, et il s'agissait d'un facteur important dans les efforts qu'ils déployaient pour s'adresser à elle. Par la montée d'émotions, elles provoquaient des actions qui étaient au-delà des intentions humaines, voire même contraires à elles. Dans ce sens, elles avaient une agency. Enfin, sous certaines conditions, elles étaient perçues comme le siège de fonctions vitales. Puisque les dieux grecs ne pouvaient se trouver en deux endroits en même temps, ils ne pouvaient pas sans cesse habituer leurs statues. Toutefois, ils manifestaient leur puissance par l'intermédiaire de la statue par épiphanie. Une statue était un réceptacle (ankeion) pour un dieu et un médium pour l'épiphanie.

\section{AUTHOR}

\section{ANGELOS CHANIOTIS}

Institute for Advanced Study - Princeton

achaniotis@ias.edu 